\title{
Exploring governance for sustainability in contexts of violence: the case of the hydropower industry in Colombia
}

\author{
Jorge-Andrés Polancoid
}

\begin{abstract}
Background: The hydropower industry in Colombia is developing in contexts of violence because of armed conflict. The companies that drive hydropower development are usually large and benefit today from lessons that have been learned around the world. However, there is little understanding of how these good management practices are addressed in contexts of violence. This paper contributes to the filling of a knowledge gap between the energy business practices and the local implications of the armed conflict. Large companies would have to incorporate a holistic view of the power generation business that connects financial performance with both environmental protection and social equity. The governance of business sustainability is analyzed within violence, drawing upon a case study from the hydropower industry to explore emergent issues, dominant players, and tools that may provide solutions.
\end{abstract}

Methods: The case study method is based on the hermeneutical analysis of 16 in-depth interviews with employees from the energy sector, the public municipalities, and local leaders. The interviews were coded and occurrence rates were used as ranking criteria. Two co-occurrence matrices were constructed in order to estimate the ranking of the interests of the players and the tools of action they prefer.

Results: The results exhibited conventional problems such as climate change, dwindling biodiversity, and the deteriorating condition of natural resources, in addition to the characteristic difficulties of armed conflicts, such as illegality, distrustfulness, and lack of opportunity for local populations. In view of both the weakness of the state and the scarcity of social capital, energy companies emerge as a central player in association with nongovernmental organizations. The tools used are more geared toward planning than they are toward joint action and evaluation.

Conclusions: It was concluded that the management of hydropower stations in the contexts of violence requires companies to orient their actions toward results and evaluate the impact of its management. Such management must be based on transformational relationships aimed at reducing the existing asymmetry between players and distributing the costs and benefits of the hydropower station more equitably.

Keywords: Governance, Sustainability, Hydropower industry, Violence, Colombia

(c) The Author(s). 2018 Open Access This article is distributed under the terms of the Creative Commons Attribution 4.0 International License (http://creativecommons.org/licenses/by/4.0/), which permits unrestricted use, distribution, and reproduction in any medium, provided you give appropriate credit to the original author(s) and the source, provide a link to the Creative Commons license, and indicate if changes were made. 


\section{Background}

Most of the electric power available in Colombia is generated by large hydropower stations [1]. More than a third of this energy supply has been developed during the years since the 1980s, when the violence as a result of armed conflict in the country grew considerably; between 1985 and 2017, approximately 7 million Colombians were forcibly displaced to other areas of the country [2, 3]. The year 2002 is known as one of the bloodiest periods, which was a result of multiple conflicts between guerillas, paramilitary groups, and the army [4]. During that year, attacks on electric power transmission networks, oil pipelines, and road infrastructure were frequent; massacres were intensified; and electoral procedures were hindered $[4,5]$.

Globally, most hydropower development is taking place in emerging economies in Asia, Africa, and South America [6]. However, Colombia is not the only country in which this development has occurred amid violence because of armed conflicts as may be observed in cases involving countries such as Myanmar [7], Angola, and the Democratic Republic of Congo [8]. Little territorial control by the state is frequently observed in these countries, as there are insurgent groups that benefit from extortion, and the local population is affected by the conflict $[9,10]$.

The companies that drive hydropower development are usually large, and this development usually involves the construction and operation of stations that produce more than $1 \mathrm{MW}$ of power [6]. Those who manage these organizations benefit today from lessons that have been learned around the world, such as that of participation in evaluating the shared benefit and that of the implementation of environmental and social management plans with the aim of complying with development policies in the energy sector and the regulations of each respective country [11].

However, these good management practices are put to the test in contexts of violence, requiring these companies to incorporate a holistic view of the power generation business that connects financial performance with both environmental protection and social equity. How do energy companies manage hydropower facilities in contexts of violence? This issue is particularly relevant for Colombia taking into consideration the fact that its electric power supply is heavily dependent on the operation of large hydropower plants that are vulnerable to armed conflict.

There is little understanding of the local implications of the armed conflict in the energy business practices in Colombia. The lack of trust and opportunities, illegality, forced displacement of people, and weakness on the part of state organizations might be the main issues of the armed conflict $[4,12]$. The energy companies have voluntary initiatives to protect their reputations and better adapt to this violent context by addressing environmental externalities, human rights, employment, and community development $[13,14]$.

However, the context of violence forces the energy firms into a key position that could maintain the asymmetry between the players if it is exploited to socially legitimize the firms rather than to create mechanisms that more equally distribute the costs and benefits of the infrastructure [15]. This paper contributes to fill the gap of knowledge about the interdependence of the hydropower industry with the territory, to understand how to share benefits more equitably in contexts of violence.

The concepts of corporate sustainability and collaborative governance form the conceptual framework of this study. The former is considered because it gives meaning to a holistic view of the business [16-18] and the latter because it explains the relationship between the business and the surrounding area under circumstances of interdependence that are characteristic of contexts of violence $[19,9]$. Through collaborative governance, firms would be able to surmount institutional constraints of corporate sustainability [20], such as social pressure, reputational effects of environmental impacts, or any other interdependency with stakeholders [21,22].

The purpose of this study was to analyze governance for sustainability in the hydropower companies that are located in contexts of violence, using a case study from the energy industry to explore the emergent issues, dominant players, and tools used in their solution. The exploratory case method employed by Yin [23] is used, inspired by other, similar works $[7,15]$. In all, 16 in-depth interviews were conducted, and the data were triangulated using secondary information. The interviews involved employees from one of the country's main power companies, public employees from state organizations, and local leaders from areas that had experienced armed conflict. The secondary information that was examined dealt with corporate sustainability, collaborative governance, and energy development in contexts of violence.

The study is divided into five sections. The first section lays in order the conceptual foundations of corporate sustainability and collaborative governance to subsequently outline the problem of managing hydropower stations in contexts of violence. The second section presents the methodological process used for characterizing the data and its qualitative analysis. The third section describes the main results of the interviews in terms of issues, players, and tools. The fourth section discusses these results in view of good management practice while highlighting specific details associated with contexts of violence. Finally, the "Conclusions" describes theoretical and practical repercussions of the main findings, the limitations of the study, and further topics for research. 


\section{Literature review}

The term corporate sustainability (CS) is more widely used in academic literature than in practitioner literature. Practitioner literature tends to be more prescriptive trying to provide guidelines to managers on how to pursue CS while academic literature tends to be more holistic, complex, and philosophical [24]. A standardized definition does not exist. However, for the renewable energy research, some authors have recently mentioned that CS definitions all emphasize the importance of meeting stakeholders' needs and balancing the economic, environmental, and social dimensions of corporate performance [25].

Based on the work of Montiel and Delgado-Ceballos [24], Baumgartner [26], and Chang et al. [25], we broadly define corporate sustainability as the ability of a firm to perform growth over time by effectively reducing economic, social, and environmental impacts and meeting the expectations of diverse stakeholders. Corporate sustainability tends to be considered in terms of company performance in conjunction with the well-being of society and environmental quality [24, 27, 28]. Therefore, future performance is seen as being dependent on the company's potential for improving its present performance [18].

Lozano [16] argues that this potential depends on factors that are internal, external, and associated with the company and its surroundings. Among the main internal factors, profitability, responsibility, and corporate culture are the most visible, whereas among the external factors, consumer interest, the growing consciousness of society, and regulations stand out. Lozano [16] emphasizes that reputation, sustainability reports, access to resources, and socio-environmental crises are connecting factors because of the fact that they provide a link between the company and its surroundings.

Ensuring the permanence of the business on the market while at the same time improving its relationship with the surroundings is a governance issue [29]. What is in play is the political and ethical position of the company, as well as its strategy, structure, and organizational culture $[26,30]$.

The concept of business ethics brings together the internal factors proposed by Lozano [16] in that it involves belief, responsibility, and virtue as expressed by the business in seeking a long-term profit [31]. On the one hand, Windolph et al. [32] speak of the belief of the company in sales, access to capital, and the assembly of a workforce. On the other hand, these authors associate the responsibility and virtue of the organization with its response to state regulation (operating licenses) and pressure brought to bear by communications media and society when they demand that corporate values be based on human rights and the protection of natural resources.
According to these terms, ethics in the context of corporate sustainability provides reliability and legitimacy because it evidences the effect that the perception of stakeholders has on company performance [33, 34]. The attainment of reliability and legitimacy through relationships with stakeholders is an issue that is related to governance of corporate sustainability, which has the potential to hinder the sustainability of companies [35-37].

Therefore, being perceived as being reliable and legitimate by the community is a sensitive issue (among others) for businesses and impinges on how benefits are distributed, in accordance with the following levels of commitment [38, 39]: (1) transactional: the business tends to compensate the community, confidence is limited, and the benefits are differentiated; (2) transitional: the community participates, resulting in greater trust, but the benefits are still differentiated; and (3) transformational: the business and the community become integrated to generate change, joint learning occurs, and the benefits are shared.

Thus, corporate sustainability refers to a firm that minimizes its impact and has an inclusive relationship with all of his stakeholders, sharing its created value for a common well-being [40]. In addition, the future performance of corporate sustainability also depends on the sustainability of the territory in which the companies are not necessarily central players as defined by business ethics [41]. Hence, territorial sustainability is more closely related to politics as the business is increasingly forced to negotiate its operation. Therefore, politics in business is perceived as being related mostly to external and connecting factors of corporate sustainability as proposed by Lozano [16].

This negotiation seeks institutional arrangements that reduce transaction costs and increase the persuasion of players to achieve mutual expediency of territorial sustainability [42, 43]. A territorial understanding of sustainability is thus necessary, as it is here that the resources (raw material, infrastructure, social capital, etc.) that make the business viable and provide for the population's livelihood are located. Therefore, these spaces for social construction must be equipped with political technologies that allow resources to be measured and their exploitation to be controlled [44]. This way, institutional arrangements will become political technologies if measures are put in place by which they may be evaluated.

Thus, collaborative governance emerges as a form of network organization in which the agents first seek to build trust and a shared understanding of the issues involved by means of deliberation and negotiation [45]. They subsequently seek to obtain resources and build skills and leadership, which translates into commitment 
to finding a joint solution to problems for which a unilateral solution is difficult to achieve [45, 46].

Collaborative governance is defined by Emerson et al. ([19], p. 2) as "the processes and structures of public policy decision making and management that engage people constructively across the boundaries of public agencies, levels of government, and/or the public, private and civic spheres in order to carry out a public purpose that could not otherwise be accomplished". According to these authors, the products of collaborative governance emerge from three types of inter-organizational dynamics:

1. Principled commitment - this describes how participants interact regarding shared interests and individual objectives, using face-to-face communication and achieving their own processes and arriving at meaningful decisions;

2. Shared motivation - this considers the dynamics and collaborative processes involving understanding, trust, legitimacy, and commitment;

3. Capacity for joint action - this is characterized by the resources necessary for sustaining the collaborative process and includes the leadership, process structure, rules of the game, quality information, budget, and time available to the collaborators.

There is a normative appeal of collaborative governance to solve complex public problems or deliver public goods and services, such as access to natural resources and energy supply, because these problems can be neither understood nor addressed by a single organization [22, 47]. Through collaborative governance, firms would be able to surmount institutional constraints of corporate sustainability [20], such as social pressure, reputational effects of environmental impacts, or any other interdependency with stakeholders [21, 22].

With this being the case, long-term business performance requires a company organization that links economics to the environment and society not only in a corporate system [17] but also with regard to ethics and politics [32,46]. This is a challenge that would connect the businesses to their surroundings in a manner that is sensitive to contexts of violence, such as in the case with the hydropower industry in Colombia.

\section{The case of the hydropower industry in Colombia}

Hydropower project development is currently occurring primarily in emerging economies in Asia, South America, and Africa, although the Balkans and the Caucasus region also figure as centers of development $[6,48,49]$. These regions possess abundant natural resources, access to which has been the cause of armed conflict and violence in cases such as those of Myanmar in Asia [7], Angola and the Democratic Republic of Congo in Africa [8], and Colombia in South America [5, 15].

According to the studies by Le Billon [9] and Springer and Le Billon [10], it is common to encounter greater state control of resources that are concentrated geographically, such as petroleum and minerals, when compared with that of scattered resources, such as agricultural land holdings. In addition, insurgent leaders may appear who maximize the return on controlling these resources consequent to their practice of extortion.

Colombia possesses a hydropower potential of approximately $56.2 \mathrm{GW}$, one of the greatest in South America, and this potential is being exploited mostly by stations with a capacity of more than $1 \mathrm{MW}[6,1]$.

The current total capacity of all installed plants is $16.9 \mathrm{GW}$, of which $69.8 \%$ came from large hydropower stations [50]. Approximately, a third of this capacity was developed after 1980, the year in which the violence in the country greatly intensified in terms of the population that was forcibly displaced (Fig. 1).

Source: National Government Victims Unit [2] and the ONG Consultancy for Human Rights and Displacement [3].

The recent violence in Colombia is a result of armed conflict waged for the purpose of territorial control (access to natural resources, strategic infrastructure, illegal economies, etc.) among guerillas, paramilitary forces, and legitimate state authorities (the army and the police). The forced displacement of populations is an aspect of this violence that is frequently trivialized and reduced to mere discussion of statistics and data [51]. However, it is also seen as evidence of the dynamics of the armed conflict $[52,12]$.

Forced displacement uproots people from their homes, breaks relationships of trust and neighborliness, and limits opportunities for work and subsistence [53, 52]. Territorial occupation, the limitation of collective action, and the destruction of the fabric of society are strategies of warfare that dictate forced displacement [12].

The numbers involved in this forced displacement reveal a dynamic of the conflict that is characterized by four key stages in connection with difficulties in the peace processes $[4,5,54]$ :

1. Guerilla expansion after the collapse of peace talks in 1984 during the government of Belisario Betancur (1982-1986) - this resulted in an increase in the mobilization of military forces from the periphery to areas of the country that were more integrated economically, as well as to large population centers.

2. The emergence of paramilitary forces in the 1990s in reaction to guerilla expansion - the 


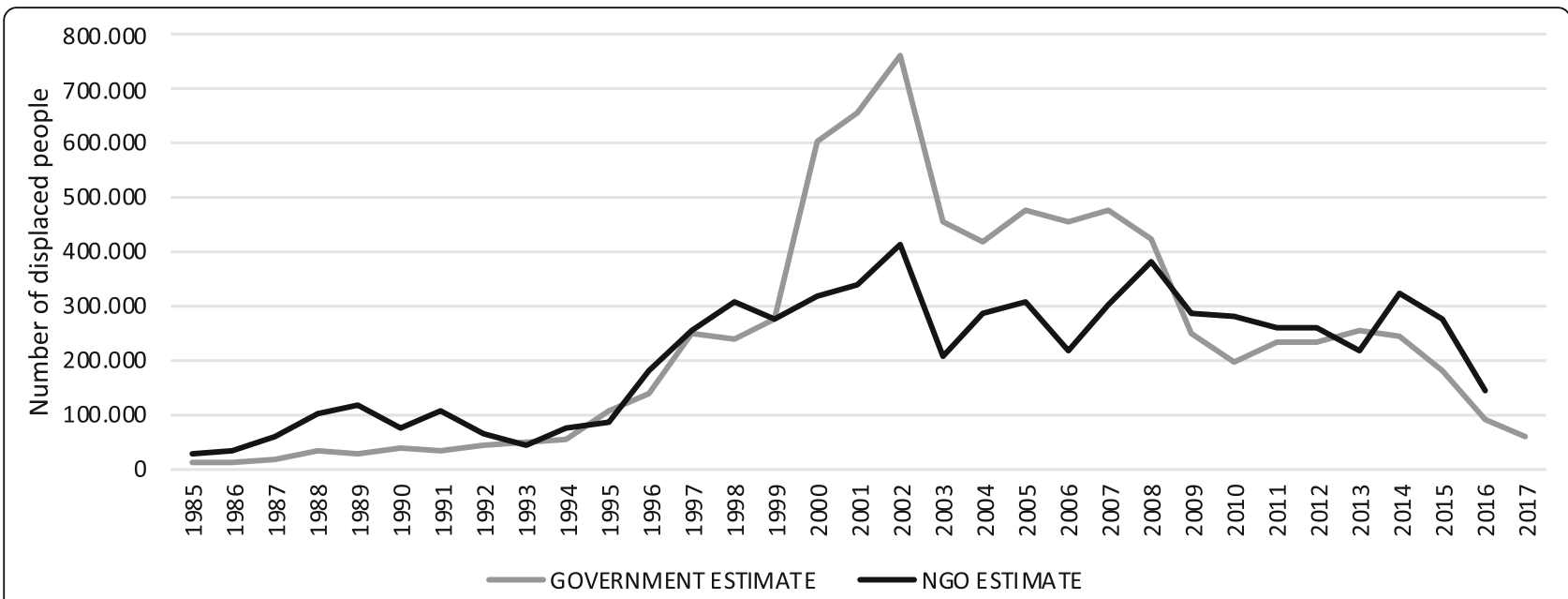

Fig. 1 The number of people who have been displaced by the violence in Colombia - This displacement may have been caused by threats against one's life, family, or property or against the freedom of association and political participation

confrontation between paramilitary forces and guerillas and the collapse of peace talks during the government of Andrés Pastrana (1998-2002) led to the greatest geographical expansion of the conflict, affecting more than half of the country.

3. The retreat of guerillas - as a result of joint efforts by the paramilitary forces and public forces during the government of Álvaro Uribe (2002-2010) and the consolidation of USA support through the Colombia Plan, the intensity of the violence decreased and part of the paramilitary forces demobilized in 2006, which was followed by the emergence of the phenomenon of "parapolitics," in which members of the Congress allegedly had ties with paramilitary groups.

4. The reorganization of guerilla forces and paramilitary groups - This came about as a result of the polarization unleashed by the Peace Accord signed in 2016 between the government of Juan Manuel Santos (2010-2018) and the leading guerilla group. The Peace Accord was endorsed by Congress after the failure of the referendum, difficulties appeared in its implementation, and violence returned to the country's periphery.

This dynamic of armed conflict makes the territory insecure, reduces the population to a condition of vulnerability, and hinders, even more, the presence of the state and energy companies. Attacks on electric power transmission networks, oil pipelines, and road infrastructure are frequent; massacres are committed; and electoral processes are hindered $[4,5]$. This has resulted in increased pressure on the population, with the number of people forcibly displaced between 1985 and 2017 being approximately 7 million $[2,3]$.
A large part of Colombia's hydropower infrastructure is located in areas that are inhabited by vulnerable populations, that have little state presence, and that are extremely rich in natural resources. Before the year 2000, large hydropower projects were commonly developed despite rejection by the local populations because of ensuing evictions, little community consultation and participation, and few economic and social benefits [55]. This resulted in social movements that were exploited by guerillas in their territorial advance by their appropriating popular demands and capturing resources that have been acquired by exploiting natural resources [5].

After 2000, energy companies strengthened their position in the territory before, after, and during the construction of large hydropower facilities not only as a result of adaptation to the contexts of violence but also as a consequence of stronger legislation and requirements by multilateral development banks [55].

Initially, the mindset of energy companies is pragmatic, reacting to the law and to conditions for accessing the capital market [56]. They then become more proactive, investigating voluntary initiatives that allow them to protect their reputations and better adapt to violent contexts [13, 14], such as the management of environmental externalities, human rights, employment, and community development.

As is seen from multiple experiences from around the world [11], the management of hydropower facilities tends to consider, on the one hand, participation as a key factor in evaluating social impact and as a structural base for the shared benefit that is sought using this power generation technology. On the other hand, environmental management plans have increasingly consolidated as tools that are integrated with the social aspect in such a way that they contribute to compliance with 
the development policies of the sector and regulations of each country.

This holistic view of the business then requires it to consider governance for sustainability in the business realm, where collaboration with the surrounding area is the determining factor. As mentioned above, the products of this collaboration are the result of principled commitment, shared motivation, and capacity for joint action [19, 46]. Therefore, the identification of these products allows one to investigate the sustainability of the hydropower-generation company in contexts of violence as shown below.

\section{Methods}

The goal of this study is to analyze governance for the sustainability of power generation businesses in contexts of recurring violence using a case study from the power industry to explore the emergent issues, dominant players, and problem-solving tools used.

The exploratory case study method employed by Yin [23] is used, considering its application in similar studies $[43,57]$. In view of the scarcity of information available and the interplay of interests involved, it was necessary to interview different players and triangulate the resulting data using secondary information. The paragraphs below present the data characteristics as their analysis strategy.

\section{Data}

This methodology is based on the hermeneutical analysis of 16 in-depth interviews with employees from the energy sector (7 interviews), public municipal employees (4 interviews), and local leaders (5 interviews). The employees from the sector are from one of the country's main private power generation companies, the hydropower stations of which are located in areas with a history of violence. The public municipal employees and local leaders belong to the sphere of influence of these power stations in areas that have experienced armed conflict involving varying levels of intensity with regard to the forced displacement of the population.

Open interviews were preferred, with the aim of "investigating a problem and understanding it as it is conceived and interpreted by the subjects being studied, without imposing preconceived categories" ([58], p. 93). Therefore, the understanding of governance for corporate sustainability is inductive.

The interviews were structured according to three analytical categories (issues, players, and tools), and the questions were asked to gather information on the subcategories therein (Table 1). Then, the interviews were recorded, transcribed, and encoded with the aid of Atlas.ti software. Subsequently, 200 codes were selected and grouped into the three analytical categories:
1. Issues (88 codes): These emphasize the type, problem, and purpose of the actions carried out by the players.

2. Players (60 codes): These refer to the agents who either live or operate in the area of influence of the hydropower stations and represent the production sector, state organizations, and organizations from civil society.

3. Tools (52 codes): These bring together the means used by the agents to carry out their roles and evaluate their operation in the area of influence of the hydropower stations.

These analytical categories were selected taking into consideration the holistic focus on sustainability [13, 59], the continuous improvement approach of corporate management $[60,61]$, and the productive performance focus on collaborative governance [19, 47]. First, the holistic perspective of sustainability concerns the triple bottom line (economy, society, and environment) and the interlinkages between dimensions. Second, the continuous improvement approach looks for the efficiency of planning, execution, and evaluation tools. Third, the performance of collaborative governance takes into account actions and outcomes of the principled commitment, the shared motivation, and the capacity for joint action of energy firms' stakeholders.

\section{Data analysis}

The encoding allowed citation frequencies to be estimated, which, in turn, were used to prioritize each issue in each of the analysis categories. The citation frequencies were used as ranking criteria-the more cited an issue the more important it is considered. Next, the citation frequencies were normalized using the minimum-maximum procedure according to $[62,63]$ :

$$
C_{N}=\frac{C-C_{\min }}{C_{\max }-C_{\min }}
$$

In which:

$C_{N}$ : normalized code within the range $(0,1)$

$C$ : citation frequency of non-normalized code

$C_{\text {min }}$ : minimum citation frequency of non-normalized code

$C_{\text {max }}$ : maximum citation frequency of non-normalized code

Once the codes were normalized, they were compared according to the perceptions of the company and the other territorial players. In this last instance, the perceptions of the local leaders and public employees at the municipal level were used. In addition, co-occurrence matrices were constructed by crossing both the "issues" and "players" categories and the "players" and "tools" 
Table 1 Descriptions of issues, players, and tools for territorial intervention

\begin{tabular}{|c|c|c|}
\hline Issues & Players & Tools \\
\hline $\begin{array}{l}\text { Society: } \\
\text { Building social capital, trust, relationships, } \\
\text { and organizational networks } \\
\text { Environment: } \\
\text { Climate change, biodiversity, and the } \\
\text { condition of natural resources, water, } \\
\text { and soil } \\
\text { Economy: } \\
\text { Power generation, budgeting, and monetary } \\
\text { compensation associated with the impact } \\
\text { of hydroelectric facilities } \\
\text { Society-environment: } \\
\text { Training, consciousness, and environmental } \\
\text { culture in the territory } \\
\text { Economy-environment: } \\
\text { The economy of natural resources } \\
\text { (supply and demand), pollution of the } \\
\text { environment, and basic sanitation } \\
\text { Economy-society: } \\
\text { Activities for subsistence, food security, } \\
\text { production organization, and } \\
\text { commercialization of farm products }\end{array}$ & $\begin{array}{l}\text { Energy companies: } \\
\text { Generators of hydropower } \\
\text { Local community: } \\
\text { Community action boards, farming, } \\
\text { and fishing cooperatives of small } \\
\text { landowners } \\
\text { Nongovernmental organizations: } \\
\text { National and local non-profit organizations } \\
\text { that exist for the fomentation of the following: } \\
\text { - Science and technology } \\
\text { - Education, environmental protection, and } \\
\text { bio-commerce } \\
\text { - Development and peace } \\
\text { The state: } \\
\text { National and local state organizations: } \\
\text { - Environmental, farming, transportation, } \\
\text { and property regulation } \\
\text { - Fomentation of technical education } \\
\text { and farming development } \\
\text { - Security } \\
\text { University: } \\
\text { Public and private higher education } \\
\text { institutions with: } \\
\text { - Scientific research } \\
\text { - Social projection } \\
\text { Organizations for development: } \\
\text { - International organizations for humanitarian } \\
\text { aid and cooperation } \\
\text { - Business foundations } \\
\text { - Guild organizations }\end{array}$ & $\begin{array}{l}\text { Planning: } \\
\text { Public and private plans, programs and projects } \\
\text { for socioeconomic development, environmental } \\
\text { protection, infrastructure, and the use of the } \\
\text { territory } \\
\text { Execution: } \\
\text { Establishing inter-institutional alliances and social } \\
\text { networks, the formation of sectorial committees, } \\
\text { and community schools for local development } \\
\text { Evaluation: } \\
\text { Verification and adjustment of the intervention } \\
\text { using communication channels, questionnaires, } \\
\text { indicators, and licenses for the operation of } \\
\text { infrastructure projects }\end{array}$ \\
\hline
\end{tabular}

categories. This type of data analysis provides the holistic and systemic vision required by the sustainability study $[64,16]$, estimating the ranking of the interests of the players and the tools of action they prefer.

The results are presented in three parts. First, the respective rankings for the issues, players, and instruments are compared according to the perceptions of the company and the other territorial players. Second, the ranking of interests and tools associated with each player is estimated. Third, the main statements made by the hydropower-generating company, public municipal employees, and local leaders concerning hydropower plant management and its relationship with violence are highlighted.

\section{Results}

The environment is the most relevant issue, followed by economy-society and society. The importance of the issue of the environment is associated with the negative impacts of hydropower-generation on water flow downstream from the dam. The issue of economy-society appears to emerge because of transportation problems affecting economic and productive activity in the territory (livestock, fishing, and agriculture).
The issue of society emerges as a result of the relationship between the local community, state organizations, and the energy company, in which context training, trust, and the construction of social capital appear as important themes. Although of less importance, the issue of economy-environment also features because of soil use that may cause deforestation, erosion, and sediment buildup. In addition, the theme of society-environment seems to demonstrate the importance of training and environmental consciousness in the territory. All these items are understood as being nonmonetary benefits. The issue of the economy has little importance for the interviewees and relates to financial resources for monetary and nonmonetary compensation.

Taking this into consideration, the state organizations (particularly the regional environmental authority), the energy company, and nongovernmental organizations (NGOs) appear as dominant players. All these players primarily make use of planning but also use execution and evaluation tools. The most prominent among the planning tools may be plans and projects that seek to coordinate players and integrate operations involving social, economic, and environmental issues. In contrast, execution tools are oriented toward the formation of 
network-building alliances and partnerships and not so much execution committees. Finally, evaluation tools appear to be limited to conducting technical studies; establishing mechanisms for communication; and to a lesser extent, audits and the establishment of measurement parameters.

It is clear that this evidence involving issues, players, and tools is dependent on the perception of the energy company and the territorial agents, including municipalities and local leaders (Fig. 2). From a territorial standpoint, the most relevant issue should be that of economy-society as a result of difficulties in carrying out productive activities. However, the company appears to consider the issue of the environment to be more significant, possibly due to the impact of the dam on the water flow or its effects on the sediments in the reservoir.

The issue of society seems to have the same relative importance for the company and the other territorial players, meaning that the relationship between them would be a determining factor because of the need for trust. The state appears to be the most important player for both. However, the company seems to give more importance to NGOs most likely due to the leadership of the Catholic Church in the Peace and Development Programs (PDP). Municipalities and local leaders give more importance to local communities because of their need for training and social and productive organization.

Finally, no differences were observed between the perception of the business and other territorial players regarding the ranking of the tools. However, it is likely that preferences do exist among the players concerning issues and tools used for their management as shown below.

\section{Issues and tools of the players}

According to the results of the co-occurrence matrices, the state entities appear to be concerned mainly about the issues of society, the environment, and economy-environment. This relationship has come about probably because of the importance that regional environmental authorities attach to protecting natural resources and to their relationship with other territorial players (Fig. 3). The state entities appear to make use of all three tools-planning, execution, and evaluation (Fig. 4).

As for the energy company, it appears to prioritize the issues of the economy, economy-society, and society-environment perhaps due to the importance attached to the business of the monetary or nonmonetary compensation fees during the operation of hydropower stations (Fig. 3). This player appears to use the tools of evaluation and planning but not so much execution in the continuous improvement process of its management (Fig. 4).

As for NGOs, the emerging issues appear to be the environment and economy-society perhaps because of their commitment to protecting the environment and the development of productive community activities. The issue of society may also be prominent due to the trust-building efforts of the PDP (Fig. 3). Thus, these organizations would be more involved in plans and alliances than they would in intervention committees (Fig. 4).

The organizations for development and the local communities would be marginalized in the interplay between players, participating tangentially as executors of projects in the areas of economy-society and

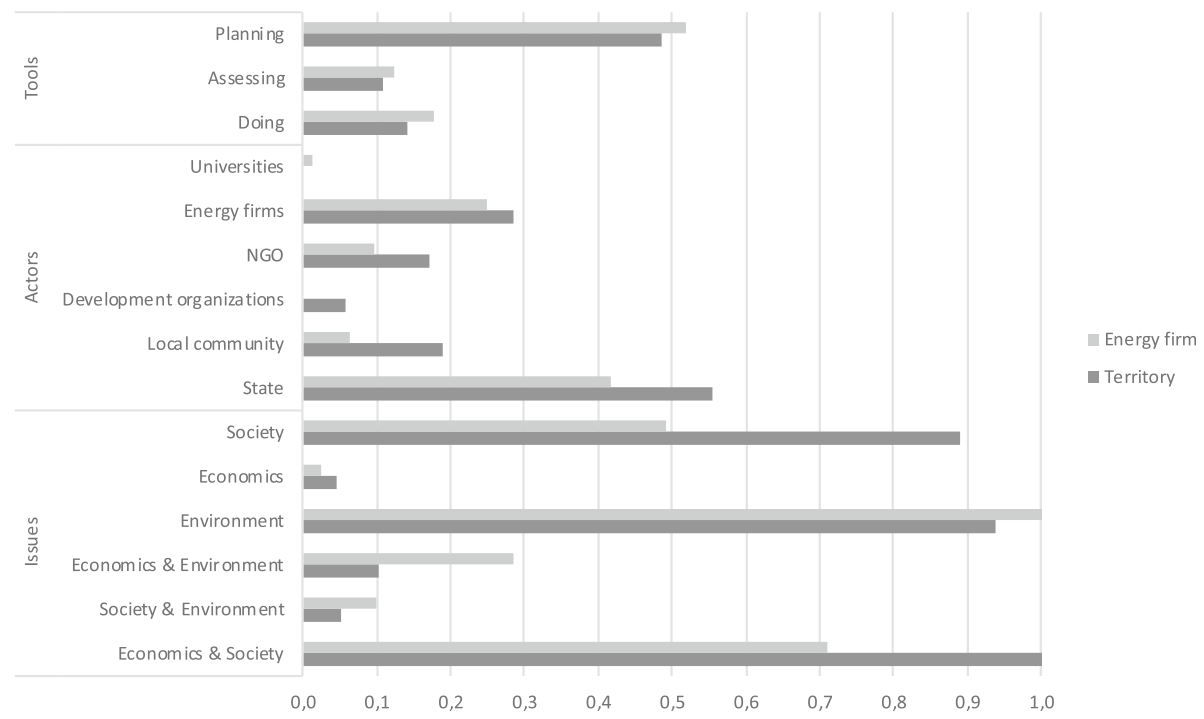

Fig. 2 Issues, players, and instruments, according to the perceptions of the territorial players and the energy company. Ranking based on the occurrence rates 


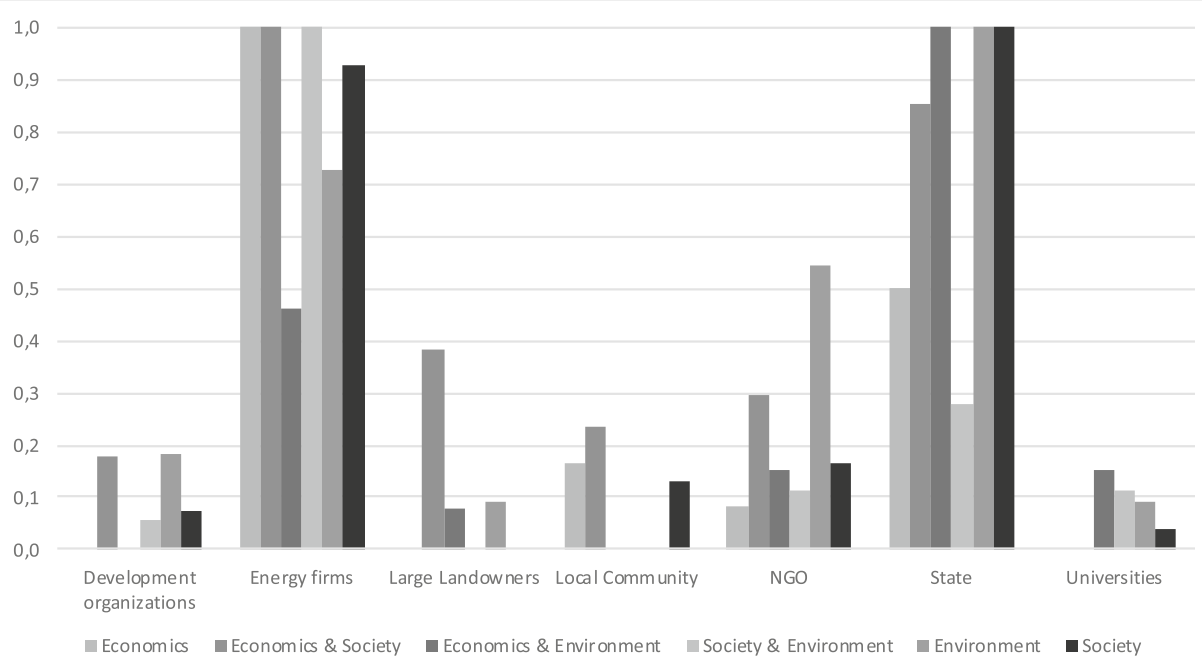

Fig. 3 The emergent issues according to the territorial players. Ranking based on the co-occurrence matrices

society (Fig. 3). Perhaps this is why they are only visibly using tools for execution (Fig. 4). Universities would be interested mainly in the issue of economyenvironment (Fig. 3), contributing modestly in the form of technical studies (Fig. 4).

In summary, state organizations, the energy company, and NGOs would dominate the interplay between players, mainly in the issues of the environment, economy-society, and society. The players would be making the most use of planning tools, thus revealing limitations involving execution and evaluation. However, this situation begins to become differentiated when the perceptions of the company, municipality, and local leadership are analyzed. This differentiation illustrates each player's own concerns although all players would appear to show the importance of their relationships in view of the need for trust. The following section presents a more in-depth examination of the interviews to illustrate the relationship of these findings with contexts of violence.

\section{Statements regarding governance for sustainability in contexts of violence}

The hydropower-generation business encounters the most difficulty because of two principal consequences of armed conflict and violence-the lack of trust and the

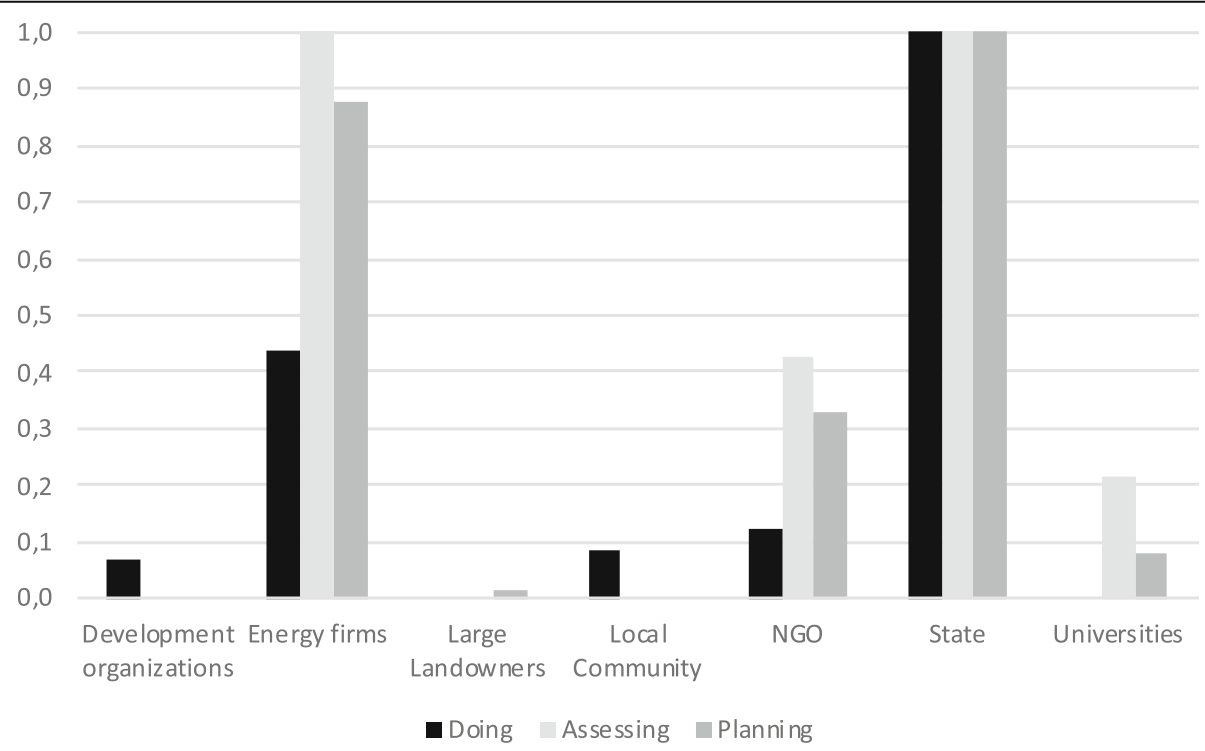

Fig. 4 The intervention tools according to the territorial players. Ranking based on the co-occurrence matrices 
lack of opportunities for the population. First, the hydropower facility is built on a territory that was controlled by guerillas in the immediately preceding period and has historical and social debts as a result of state absence.

This situation creates an expectation for compensation on the part of the local community, which is what the energy company in question was apparently unwilling to satisfy, imputing responsibility to the state in some cases or with humanitarian efforts in others: "The construction of the hydropower plant generated expectations in the community that the company did not accept because it considered them to be the responsibility of the state or humanitarian programs." (energy company's statements).

The same situation may occur in the construction of auxiliary infrastructure (transfers) as the local community expresses displeasure with the environmental impacts and their management on the part of the company: "Tension exists between the communities and the energy company due to the reduction of water flow in some gorges, which is perceived to be the result of the construction of transfers that feed into the reservoir. However, the energy company is working with the communities to resolve the problem." (municipalities' statements).

Presumably, included in this opposition were community organizations that were sympathetic to leftist political ideologies, which they had probably inherited from the guerillas: "The local communities have lived together with two players that have transformed the territory. First, insurgent groups occupied the spaces left by the State. Second, the energy company builds the hydropower facility and the transfers. Mistrust and opposition exist in local communities toward the energy company, in some cases led by leftist organizations." (local leaders' statements).

The distrustfulness is probably one of the main issues of hydropower governance in contexts of violence. On the one hand, it might be the consequence of a project's life cycle assessment without a community participation in the construction stage: "The mistrust is also based on the lack of communication, particularly in the transfer construction stage." (local leaders' statements). On the other, however, it could also be seen as a result of both the armed conflict and the historical and social debts: "The building of trust must confront historical and social debts, but the company progresses with information, participation, and community development programs" (energy company's statements). Moreover, "After armed conflict and the construction of the hydropower facility, development and peace programs appeared, which were led by the Church, bringing together local communities, the State, and the private sector." (local leaders' statements).

Second, the lack of opportunities is presumably related to land access, economic activities, and productive organization in a climate of illegality. According to the statements of the energy company and the municipalities, economic activities are being developed with the support of the central government: "Community economic activities are encouraged in association with the municipalities, from production to commercialization. Attempts are being made to use the reservoir for the development of tourism by the communities." (energy company's statements). Additionally, "Mechanized farming development, agricultural inputs, and technical assistance are being supported. This work is carried out mainly by an alliance with the Ministry of Agriculture and also with energy companies in some cases." (municipalities' statements). However, absentee landowners of large territories (mostly livestock breeders) are observed along with small farmers who sometimes do not have deeds to their land and encounter difficulties in production and commercialization. Artisanal fishermen also exist, who occupy state or private territory, particularly riverbanks: "Both large and small landowners exist. The large landowners usually work with livestock, and neither live nor are interested in the area. The small landowners are farmers and fishers who have a subsistence economy. Many of the fishers are not landowners and occupy de facto state and private property. A large part of the work of those who dwell in the country is informal; they are usually paid on a daily basis." (local leaders' statements).

The illegality appears to be related not only to land ownership but also to economic activity as several statements call attention to the presence of illicit crops and illegal mining tied to criminal gangs: "Community-based ecotourism exists although its organization is incipient. These communities have difficulties with the energy company due to the river flow management. The guerillas had ties with the livestock business." (municipalities' statements). Furthermore, "The state and energy companies are finding it difficult to support these country economies due to the low level of local capabilities. In addition, illegal mining is carried out by criminal gangs in the context of insecurity." (local leaders' statements).

Thus, the main difficulty of this situation appears to be the lack of action and evaluation. Evidence presumably exists for integral and inter-institutional planning exercises geared mostly toward building trust and creating new opportunities for the population: "The institutional relationship has improved as a result of new integrated action plans, in which the municipality, regional environmental authority, energy company, and the Church participate. As a result of this relationship, economic, social, and environmental projects are formulated in which community organizations participate." (municipalities' statements). 
Even so, the institutional relationship has not improved as much as it has in others hydropower plants where the energy company had had more experience in the territory: "Collaborative networks are being built through inter-institutional projects although conflicts of interest exist with regional environmental authorities. The results are not as visible as they are in other areas where the business has been established for more time because mistrust is still instilled in some cases by social leaders with leftist political ideology." (energy company's statements).

The power company appears to be preoccupied with the increase in compensation costs, and presumably, there are still no parameters in place for measuring and evaluating the impact of the investments in the territory: "The cost of the compensations has increased and the company does not yet have indicators that allow it to measure the impact of its management in the area of influence of the hydropower facility." (energy company's statements).

On the one hand, state organizations appear to depend on these resources: "Communities are informed concerning how to use monetary compensations (transfers from the electric sector by law) of which the municipalities are beneficiaries, which is not welcomed by the municipalities because it reduces their control of the budget." (energy company's statements). On the other, local leaders appear to have the sense that the resources are being used inefficiently: "The energy company generated many jobs directly during the construction of the hydropower facility and its transfers. During operation, the job offer reduced considerably, being limited to the management of environmental impact." (local leaders' statements).

With this being the case, the hydropower-generation company's governance for sustainability appears to be occurring in the context of mistrust and lack of opportunity, seeking as it does to coordinate interests between players with sharp differences in resources and capacity.

\section{Discussion}

Some of the elements observed in this study are also found in the context of hydropower development in other countries, particularly regarding the economic, social, and environmental impact, as well as some problematic areas for their management by the power companies. However, the context of violence makes Colombia a territory in which these companies are experiencing greater interdependence with the dynamics of the surroundings. It is perhaps for this reason that they presumably need to build new organization models that are more collaborative despite the mistrust and differences emanating from other players with regard to resources and capacity.
The fragmentation of river flow; the limits put to access to natural resources, such as fish; and the disproportionate distribution of the costs and economic benefits between the energy companies, the state, and the local communities are some of the developmental impacts resulting from hydropower development in Colombia that also exists in other countries $[6,11]$.

Although in this case, managing these impacts involves compliance with regulations and the use of international standards such as the sustainability protocol of the International Hydropower Association [13], difficulties are observed in other aspects, such as the fragmentation of the life cycle of hydropower projects (construction problems inherited by the operation stage); nonexistent or uncertain data for making decisions; and dependence on technical solutions to the detriment of more holistic solutions [65, 57].

In addition, the management of hydropower projects in contexts of violence from armed conflict also faces the lack of trust, the lack of opportunities, illegality, and weakness on the part of state organizations. As in other cases $[9,10]$, the control of the state is visible only in the presence of the army at the hydropower facility because of the likely presence of illicit crops and illegal mining in the areas surrounding the towns. It is probably for this reason that the presence of the army does not necessarily contribute to the security of the local community as explained by Ibáñez and Vélez [12].

Other state entities, such as municipalities, are growing stronger as a result of NGO support led by the Catholic Church and financed by the national private sector, particularly by the energy company. This kind of alliance between NGOs and the energy company is common in Latin America [14], whereas in Asian countries such as China [57] and India [66], it is seen as an aspect that needs to be improved because of NGOs' opposition to hydropower development.

By occupying a marginal role between players in the territory, local communities appear not to be affecting state entities as appears to be the case in other countries with armed conflict, such as Myanmar [7]. In actuality, the lack of opportunities and mistrust appear to limit the development of community organization systems based on neighborliness and solidarity [67].

As the end of the armed conflict is being discussed and many displaced families are returning to their territories [4], the reorganization of guerilla and paramilitary forces is being observed as a result of difficulties in the legitimization and implementation of the La Habana Peace Accord with the main guerilla group in the country [54]. Daniel Pécaut, in an interview by Valencia Gutiérrez [54], argues that in this context, the state must respond to the challenge to go through with reforms that not only fulfill the commitments of the La Habana 
treaty but also address the great inequality that has characterized Colombia. According to Pécaut, the presence of state institutions throughout the territory must be a priority so as to accomplish this goal.

Although the energy company may be neither able nor willing to take on responsibilities of the state, the history of state absence and the marginalization of the local communities appear to force the energy industry into a key position in the construction of these institutions. Nevertheless, Duarte-Abadía et al. [15] indicate that this centrality could potentially maintain the asymmetry between the players if it is exploited to socially legitimize the hydropower company rather than to create mechanisms that more equally distribute the costs and benefits of the infrastructure.

In one way or another, the context of violence and the centrality of the energy company appear to be defining the interdependence of the power generation company with the territory in which the hydropower facility is located. This interdependence appears to be reflected also in the emergent products of collaborative governance as defined by the inter-organizational dynamic [19, 45, 46]. Also being developed are plans and projects, which are associated with principled commitment and shared motivation, more than alliances, partnerships, technical studies, and mechanisms for communication, which are more associated with the capacity for shared action.

In other words, on the one hand, territorial planning is presumably being carried out in an integrated and inter-institutional manner to overcome the differences between the players. On the other hand, however, illegality, mistrust, the transactional relationship, inefficient use of resources, and the lack of measures are limiting commitment, execution, and evaluation. These limitations are presumably reducing opportunities for transformational learning as is also the case in India $[66,68]$, given the continuing difference between costs and benefits and opposition from local communities. However, other cases stand out, mainly from Southeast Asia [69, 68], where the difficulties involving inclusion that are characteristic of multilateral partnerships are being overcome by the construction of regional and polycentric mechanisms for coordination and participation.

\section{Conclusions}

Hydropower-generation companies in contexts of violence due to armed conflict such as that occurring in Colombia appear to be intensifying their interdependence with the territories in which the hydropower facilities operate. This seems to be emerging as a result of collaborative governance in which the products contribute more to planning than they do to joint execution and evaluation.
Theoretically, this approximation toward the issue of governance for the sustainability of business reveals the factors for corporate sustainability proposed by Lozano [16] and its relationship with collaborative governance as put forth by Emerson et al. [19]. On the one hand, factors of sustainability appear to explain the link between the performance of energy companies and the sustainability of the territories in which hydropower facilities operate. However, this link has been dealt with in this work more from the standpoint of ethics $[33,34]$ and politics [41] than from that of the corporate system [17]. It has been dealt with more from an ethical and political perspective because of the evidence of problems involving legitimacy (trust) and power (centrality) on the part of the business considered in this study in the surroundings. The corporate system perspective was not emphasized because the configuration of the strategy and its relationship to the structure and corporate culture lie outside the scope of this study.

On the other hand, responsibility, access to resources, regulations, and the socio-environmental impact of the company under consideration were the main corporate sustainability factors that allowed a conceptual association with collaborative governance. Consequently, it was possible to propose a theoretical relationship between business sustainability and the inter-organizational dynamic characteristic of the surroundings with regard to principled commitment, shared motivation, and capacity for joint action. This relationship proved to be very useful in conducting the search for governance products. However, as established by the works of Ulibarri [45] and Ulibarri and Scott [46], it would be necessary to analyze the organizational networks to explain how collaborative governance could translate into joint action.

Thus, in practice, the features of collaborative governance observed here appear to suggest voluntary actions on the part of the energy company as a product of deliberation, negotiation, and even lobbying with state organizations [70]. However, hydropower development and the evolution of the armed conflict appear to be placing the company in a key position amid illegality, a state whose territorial possession is still weak, apparently inefficient use of resources, and little social capital for collaborative work.

To adapt to this context, collaborative governance, on the one hand, should be geared more toward results [47], requiring political technologies that contribute to the measurement and evaluation of the impact of the management $[71,44]$. On the other hand, it should be directed toward reducing the asymmetry that exists between the players by building competencies and leadership [46] as well as toward distributing the costs and benefits of hydropower-generation in a more equitable manner [15]. 
A more equitable benefit distribution by collaborative actions is one of the most important hydropower sustainability issues in conflict areas, having also implications in the energy market because of its effects in the local security of energy supply [72]. Colombia does not have any energy deficit according to the public information [50], but most of the energy supply depends on power plants located in conflict areas. Thus, local security of energy supply should be addressed with the commitment of local community, state entities, and energy firms if more large dams are to be built or continue to operate in conflict areas.

Due to the exploratory nature of this case study, the presentation has been limited to hypothetical assertions concerning governance for sustainability in the hydropower generation business. These assertions are capable of defining the problem and providing clues for its solution.

However, it is suggested that future investigations analyze the incidence of inter-organizational dynamics on the corporate system; expand the discussion to include other case studies; and the opinion of academics, NGOs, and state organizations both on the regional and national levels. In addition, the use of quantitative studies would contribute toward explaining the extent to which the sustainability of the power generation business depends on the territory, as well as the contribution of collaborative governance products to joint action.

\section{Acknowledgements}

Thanks are due to the students from the doctorate program of Management of the University of Medellín, who supported the data collection process and on-site field interviews, especially to Juliana Ceballos. Thank you very much to my colleague Fabián Ramírez. I am also grateful to Dr. Stephen Sparkes from Statkraft, Norway, who gave me a very important feedback of the manuscript.

\section{Funding}

This work was supported by the Colombian state agency of science Colciencias, the University of Medellín, and the energy company (FP44842034-2016)

\section{Availability of data and materials}

The datasets used and/or analyzed during the current study are available from the corresponding author on reasonable request.

\section{Authors' contributions}

The author read and approved the final manuscript.

\section{Ethics approval and consent to participate}

All respondents in the study have been informed about the usage of the information they provide through interviews and have given their consent to participate in the study.

\section{Consent for publication}

The respondents of the study have given their consent for the data to be used and published in this scientific article.

\section{Competing interests}

The author declares that he has no competing interests.

\section{Publisher's Note}

Springer Nature remains neutral with regard to jurisdictional claims in published maps and institutional affiliations.

Received: 13 July 2018 Accepted: 18 November 2018

Published online: 03 December 2018

\section{References}

1. Unidad de Planeación Minero Energética (2016) Plan de expansión de referencia. Generación-Transmisión 2015-2029. UPME, Bogotá

2. Unidad de Victimas De Colombia (2018) Desplazamiento de personas. https:// cifras.unidadvictimas.gov.co/Home/Desplazamiento. Accessed 22 Jan 2018.

3. CODHES (2018) Sistema de Información sobre Derechos Humanos y Desplazamiento. Available: http://www.codhes.org/. Accessed 23 Jan 2018.

4. González F (2014) Poder y violencia en Colombia. Odecofi - Cinep Colciencias, Bogotá

5. Centro Nacional de Memoria Histórica (2016) Granada: memorias de guerra, resistencia y reconstrucción. CNMH - Colciencias - Corporación Región, Bogotá

6. Zarfl C, Lumsdon A, Berlekamp J, Tydecks L, Tockner K (2014) A global boom in hydropower dam construction. Aquatic Sci 77(1):161-170. https:// doi.org/10.1007/s00027-014-0377-0

7. Suhardiman D, Rutherford J, Bright SJ (2017) Putting violent armed conflict in the center of the Salween hydropower debates. C Asian Studies 49(3): 349-364. https://doi.org/10.1080/14672715.2017.1328284

8. Addison T, Le Billon P, Murshed SM (2002) Conflict in Africa: the cost of peaceful behaviour. J of African Econo 11(3):365-386. doi:https://doi.org/10. 1093/jae/11.3.365

9. Le Billon P (2001) The political ecology of war: natural resources and armed conflict. Political Geo 20:561-584. https://doi.org/10.1016/S09626298(01)00015-4

10. Springer S, Le Billon P (2016) Violence and space: An introduction to the geographies of violence. Political Geo 52:1-3. https://doi.org/10.1016/j. polgeo.2016.03.003

11. United Nations Environmental Program (2007) Dams and development. Relevant practices for improved decision-making. UNEP-DDP, Nairobi

12. Ibáñez AM, Vélez CE (2008) Civil conflict and forced migration: the micro determinants and welfare losses of displacement in Colombia. World Dev 36(4):659-676. https://doi.org/10.1016/j.worlddev.2007.04.013

13. Polanco J, Ramírez F (2017) La evaluación de la sostenibilidad en empresas de energía. Una investigación aplicada a centrales de generación hidroeléctrica. Sello Editorial Universidad de Medellín \& ISAGEN, Medellín

14. Valor C (2012) The contribution of the energy industry to the millennium development goals: a benchmark study. J of Business Ethics 105:277-287. https://doi.org/10.1007/s10551-011-0970-2

15. Duarte-Abadía B, Boelens R, Roa-Avendaño T (2015) Hydropower, encroachment and the re-patterning of hydrosocial territory: the case of Hidrosogamoso in Colombia. Human Org 74(3):243-254. https://doi.org/10. 17730/0018-7259-74.3.243

16. Lozano R (2015) A holistic perspective on corporate sustainability drivers. Corp Soci Resp Envir Manag 22:32-44. https://doi.org/10.1002/csr.1325

17. Lozano R (2012) Toward better embedding sustainability into companies' systems: an analysis of voluntary corporate initiatives. J Clea Prod 25:14-26. https://doi.org/10.1016/j.jclepro.2011.11.060

18. Schneider A, Meins E (2012) Two dimensiones of corporate sustainability assessment: toward a comprehensive framework. Busi Stra Envi 21:211-222. https://doi.org/10.1002/bse.726

19. Emerson K, Nabatchi T, Balogh S (2012) An integrative framework for collaborative governance. J of Publ Admi 22(1):1-29. https://doi.org/10. 1093/jopart/mur011

20. Moratis L (2016) Consequences of collaborative governance in CSR: an empirical illustration of strategic responses to institutional pluralism and some theoretical implications. Business Society R 121(3):415-446. https://doi. org/10.1111/basr.12093

21. Husted B, Sousa Filho J (2017) The impact of sustainability governance, country stakeholder orientation, and country risk on environmental, social, and governance performance. J of Clean Prod 155:93-102. https://doi.org/ 10.1016/j.jclepro.2016.10.025

22. MacDonald A, Clarke A, Huang L (2018) Multi-stakeholder partnerships for sustainability: designing decision-making processes for partnership capacity. J Business Ethics. https://doi.org/10.1007/s10551-018-3885-3 
23. Yin R (2009) Case study research. In: Design and Methods. SAGE, Los Angeles

24. Montiel I, Delgado-Ceballos J (2014) Defining and measuring corporate sustainability: are we there yet? Org Envi 27(2):113-139. https://doi.org/10. $1177 / 1086026614526413$

25. Chang R, Zuo J, Zao Z, Zillante G, Gan X, Soebarto V (2017) Evolving theories of sustainability and firms: history, future directions and implications for renewable energy research. Renew Sustain Energy $R$ 72:48-56. https://doi.org/10.1016/j.rser.2017.01.029

26. Baumgartner R (2014) Managing corporate sustainability and CSR: a conceptual framework combining values, strategies and instruments contributing to sustainable development. Corp Soci Resp and Envir Mang 21:258-271. https://doi.org/10.1002/csr.1336

27. Whiteman G, Walker B, Perego P (2013) Planetary boundaries: ecological foundations for corporate sustainability. J Manag Stud 50(2):307-336. https://doi.org/10.1111/j.1467-6486.2012.01073.x

28. Hahn T, Figge F, Pinkse J, Preuss L (2010) Trade-offs in corporate sustainability: you cannot have your cake and eat it. Busi Strat and the Envi 19:217-229. https://doi.org/10.1002/bse.674

29. Amini M, Bienstock C (2014) Corporate sustainability: an integrative definition and framework to evaluate corporate practice and guide academic research. J of Clea Prod 76:12-19. https://doi.org/10.1016/j. jclepro.2014.02.016

30. Linnenluecke M, Griffiths A (2010) Corporate sustainability and organizational culture. J of World Busi 45:357-366. https://doi.org/10.1016/j. jwb.2009.08.006

31. Patrus-Pena R Pessoa de Castro P (2010) Ética nos Negócios. Condicoes, Desafios e Riscos. Editora Atlas. Sao Paulo

32. Windolph SE, Harms D, Schaltegger S (2014) Motivations for corporate sustainability management: contrasting survey results and implementation. Corp Soci Resp Envi Mana 21:272-285. https://doi.org/10.1002/csr.1337

33. Costa R, Menichini T (2013) A multidimensional approach for CSR assessment: the importance of the stakeholder perception. Expe Syst with Appl 40:150-161. https://doi.org/10.1016/j.eswa.2012.07.028

34. Hahn R, Lulfs R (2014) Legitimizing negative aspects in GRI-oriented sustainability reporting: a qualitative analysis of corporate disclosure strategies. J of Busi Ethics 123:401-420. https://doi.org/10.1007/s10551-013-1801-4

35. Chen R (2014) An integrated sustainable business and development system: thoughts and opinions. Sustainability 6:6862-6871. https://doi.org/10.3390/ su6106862

36. Musson A (2012) The build-up of local sustainable development politics: a case study of company leaders in France. Ecol Econ 82:75-87. https://doi. org/10.1016/j.ecolecon.2012.07.012

37. Ageron B, Gunasekaran A, Spalanzani A (2012) Sustainable supply management: an empirical study. Int J of Prod Econ 140:168-182. https:// doi.org/10.1016/j.ijpe.2011.04.007

38. Peloza J, Falkenberg $L$ (2009) The role of collaboration in achieving corporate social responsability objetives. Calif Manag R 51(3):95-113. https:// doi.org/10.2307/41166495

39. Bowen F, Newenham-Kahindi A, Herremans I (2008) Engaging the community: a systematic review. Research Network for Business Sustainability, Ontario

40. Jerónimo Silvestre W, Antunes P, Leal Filho W (2016) The corporate sustainability typology: analyzing sustainability drivers and fostering sustainability at enterprises. Tech Econ Develop Econ 24(2):1-21. https://doi. org/10.3846/20294913.2016.1213199

41. Wildhagen R, Teodósio A, Mansur Y, Polanco J (2015) Novas fronteiras teóricas para a responsabilidade social empresarial: o papel das empresas no desenvolvimiento sustentável dos territórios. R Gest Soci Ambi 9(3):3-23. https://doi.org/10.5773/rgsa.v9i3.1051

42. Lookwood M (2010) Good governance for terrestrial protected areas: a framework, principles and performance outcomes. J Envi Manag 91(3):754766. https://doi.org/10.1016/j.jenvman.2009.10.005

43. Polanco J (2014) La responsabilidad social del Grupo EPM: una nueva postura política frente al territorio. Cuad Admi 27(49):65-85. https://doi.org/ 10.11144/Javeriana.cao27-49.rsge

44. Elden S (2010) Land, terrain, territory. Prog Human Geo 34(6):799-817. https://doi.org/10.1177/0309132510362603

45. Ulibarri N (2015) Tracing process to performance of collaborative governance: a comparative case study of federal hydropower licensing. Poli Stud J 43(2):283-308. https://doi.org/10.1111/psj.12096
46. Ulibarri N, Scott T (2017) Linking network structure to collaborative governance. J Publ Admi Res Theo 27(1):163-181. https://doi.org/10.1093/ jopart/muw041

47. Emerson K, Nabatchi T (2015) Evaluating the productivity of collaborative governance regimes: a performance matrix. Public Perf Manag R 38(4):717747. https://doi.org/10.1080/15309576.2015.1031016

48. Koutsoyiannis D (2011) Scale of water resources development and sustainability: small is beautiful, large is great. Hydr Scie J 56(4):553-575. https://doi.org/10.1080/02626667.2011.579076

49. Shen Y, Chou C, Lin G (2011) The portfolio of renewable energy sources for achieving the three E policy goals. Energy 36:2589-2598. https://doi.org/10. 1016/j.energy.2011.01.053

50. XM (2018) PARATEC. Capacidad efectiva por tipo de generación. http:// paratec.xm.com.co/paratec/SitePages/generacion.aspx?q=capacidad. Accessed 29 Aug 2018.

51. Oslender U (2016) The banality of displacement: discourse and thoughtlessness in the internal refugee crisis in Colombia. Political Geo 50: 10-19. https://doi.org/10.1016/j.polgeo.2015.08.001

52. Raleigh C (2011) The search for safety: the effects of conflict, poverty and ecological influences on migration in the developing world. Glob Envi Chan 21:82-93. https://doi.org/10.1016/j.gloenvcha.2011.08.008

53. Bryan T, Gerkey D (2016) Dams and population displacement on China's Upper Mekong River: implications for social capital and social-ecological resilience. Glob Envir Chan 36:153-162. https://doi.org/10.1016/j.gloenvcha. 2015.11 .008

54. Valencia Gutiérrez A (2017) Daniel Pécaut. En busca de la nación colombiana. Penguin Random House, Bogotá

55. Polanco J (2016) L'État décentralisé a l'épreuve de la gouvernance. Protection de l'environnement, développement économique et incertitude dans un territoire émergent. Le cas du systeme de Páramos Hauts-Andins d'Antioquia (Colombie). ANRT, Lille

56. Polanco J, Ramírez F, Orozco M (2016) Incidencia de estándares internacionales en la sostenibilidad corporativa: una perspectiva de la alta dirección. Est Ger 32(139):181-192. https://doi.org/10.1016/j.estger.2016.05.002

57. Liu J, Zuo J, Sun Z, Zillante G, Chen X (2013) Sustainability in hydropower development-a case study. Ren Sustai Ener R 19:230-237. https://doi.org/ 10.1016/j.rser.2012.11.036

58. Bonilla-Castro E, Rodríguez P (1997) Más allá del dilema de los métodos. La investigación en ciencias sociales. Ediciones Uniandes, Santafé de Bogotá

59. Bhandari R, Saptalena L, Kusch W (2018) Sustainability assessment of a micro hydropower plant in Nepal. Ener Sust Soc 8(3):1-15. https://doi.org/ 10.1186/s13705-018-0147-2

60. Camilleri M (2015) Environmental, social and governance disclosures in Europe. Sust Accou Manag and Poli J 6(2):224-242. https://doi.org/10.1108/ SAMPJ-10-2014-0065

61. Moldavska A (2017) Defining organizational context for corporate sustainability assessment: cross-disciplinary approach. Sustainability 9(12):1-25. https://doi.org/10.3390/su9122365

62. Singh R, Murty H, Gupta S, Dikshit A (2012) An overview of sustainability assessment methodologies. Ecol Indi 15:281-299. https://doi.org/10.1016/j. ecolind.2011.01.007

63. Zhou L, Tokos H, Krajnc D, Yang Y (2012) Sustainability performance evaluation in industry by composite sustainability index. Clean Tech Envi Policy 14(5):789-803. https://doi.org/10.1007/s10098-012-0454-9

64. Lozano R, Huisingh D (2011) Inter-linking issues and dimensions in sustainability reporting. J Clean Prod 19:99-107. https://doi.org/10.1016/j. jclepro.2010.01.004

65. Hussey K, Pittock J (2012) The energy-water Nexus: managing the links between energy and water for a sustainable future. Ecol and Soci 17(1):31. https://doi.org/10.5751/ES-04641-170,131

66. Diduck A, Pratap D, Sinclair A, Deane S (2013) Perceptions of impacts, public participation, and learning in the planning, assessment and mitigation of two hydroelectric projects in Uttarakhand, India. Land Use Poli 33:170-182. https://doi.org/10.1016/j.landusepol.2013.01.001

67. Forero-Pineda C, Wills Herrera E, Andonova V, Orozco Collazos L, Pardo O (2014) Violence, insecurity and hybrid organizational forms: a study in conflict-ridden zones in Colombia. The J of Deve Stud 50(6):789-802. https://doi.org/10.1080/00220388.2013.874554

68. Buechler S, Sen D, Khandekar N, Scott C (2016) Re-linking governance of energy with livelihoods and irrigation in Uttarakhand, India. Water 8(10):122. https://doi.org/10.3390/w8100437 
69. Chen H, Zhu T (2016) The complexity of cooperative governance and optimization of institutional arrangements in the Greater Mekong Subregion. Land Use Poli 50:363-370. https://doi.org/10.1016/j.landusepol. 2015.09.030

70. Feichtinger J, Pregernig M (2016) Beyond mandated participation: dealing with hydropower in the context of the water framework directive. Envi Policy and Gove 26(5):351-365. https://doi.org/10.1002/eet.1699

71. Lindström A, Ruud A (2017) Who's hydropower? From conflictual management into an era of reconciling environmental concerns; a retake of hydropower governance toward win-win solutions? Sustainability 9(7):1-18. https://doi.org/10.3390/su9071262

72. Kirchherr J, Charles KJ, Walton M (2017) The interplay of activists and dam developers: the case of Myanmar's mega-dams. I J Water Res Dev 33(1):111-131. https:/doi.org/10.1080/07900627.2016.1179176

Ready to submit your research? Choose BMC and benefit from:

- fast, convenient online submission

- thorough peer review by experienced researchers in your field

- rapid publication on acceptance

- support for research data, including large and complex data types

- gold Open Access which fosters wider collaboration and increased citations

- maximum visibility for your research: over $100 \mathrm{M}$ website views per year

At $\mathrm{BMC}$, research is always in progress.

Learn more biomedcentral.com/submissions 